\title{
EFFECT OF THERMAL AGING ON THE CORROSION BEHAVIOR OF WROUGHT AND WELDED ALLOY 22.
}

\author{
Raúl B. Rebak, Tammy S. Edgecumbe Summers and Tiangan Lian \\ Lawrence Livermore National Laboratory, Livermore, CA, USA \\ Ricardo M. Carranza \\ Comisión Nacional de Energía Atómica, Buenos Aires, Argentina \\ Jeffrey R. Dillman, Tina Corbin and Paul Crook \\ Haynes International Inc., Kokomo, IN, USA
}

\begin{abstract}
Alloy 22 (UNS N06022) is a candidate material for the external wall of the high level nuclear waste containers for the potential repository site at Yucca Mountain. In the mill-annealed (MA) condition, Alloy 22 is a single face centered cubic phase. When exposed to temperatures on the order of $600^{\circ} \mathrm{C}$ and above for times higher than $1 \mathrm{~h}$, this alloy may develop secondary phases that are brittle and offer a lower corrosion resistance than the MA condition. The objective of this work was to age Alloy 22 at temperatures between $482^{\circ} \mathrm{C}$ and $800^{\circ} \mathrm{C}$ for times between $0.25 \mathrm{~h}$ and $3,000 \mathrm{~h}$ and to study the corrosion performance of the resulting material. Aging was carried out using wrought specimens as well as gas tungsten arc welded (GTAW) specimens. The corrosion performance was characterized using standard immersion tests in aggressive acidic solutions and electrochemical tests in multi-component solutions. Results show that, in general, in aggressive acidic solutions the corrosion rate increased as the aging temperature and aging time increased. However, in multi ionic environments that could be relevant to the potential Yucca Mountain site, the corrosion rate of aged material was the same as the corrosion rate of the MA material.
\end{abstract}

Keywords: high-level nuclear waste, nickel-based alloy, N06022, aging, corrosion resistance, electrochemical behavior, immersion tests, ASTM G 28 A, hydrochloric acid, J-13 water, concentrated well water. 


\section{INTRODUCTION}

Alloy 22 (UNS N06022) is a nickel-based alloy, which contains approximately $22 \%$ chromium (Cr), $13 \%$ molybdenum (Mo), 3\% tungsten (W) and 3\% iron (Fe). UNS N06022 has excellent resistance to pitting corrosion, crevice corrosion and stress corrosion cracking in halide containing environments. ${ }^{1.11}$ Consequently, Alloy 22 is a candidate material to fabricate the external layer of the high level nuclear waste containers for the potential repository site in Yucca Mountain, Nevada. ${ }^{2-13}$

Due to the heat generated by the radioactive decay of the waste, the containers might experience temperatures as high as $160^{\circ} \mathrm{C}$ during their first 1000 years of emplacement. The lifetime design of the containers is 10,000 years. Previous studies have shown that the mechanical and corrosion properties of Alloy 22 did not change when it was aged for up to $40,000 \mathrm{~h}$ at $427^{\circ} \mathrm{C} .{ }^{4,6}$ However, it is known that precipitation of detrimental second phases occurs when Alloy 22 is aged at temperatures above $600^{\circ} \mathrm{C}^{13-19}$ The precipitation of these secondary phases that are formed at temperatures approximately $600^{\circ} \mathrm{C}$ and higher affect the corrosion resistance in aggressive acidic solutions and the mechanical properties of wrought Alloy $22 .{ }^{13-19}$

The purpose of this work was to study the effect of aging time and aging temperature on the corrosion behavior of Alloy 22 welds in aggressive acidic solutions. Similarly, this paper also addresses the effect of secondary phase precipitation on the anodic behavior of wrought Alloy 22 in multi-component electrolyte solutions that may result from evaporative experiments of ground waters from Yucca Mountain. ${ }^{20}$

\section{EXPERIMENTAL TECHNIQUE}

Three different sets of experiments are described in this paper. Two sets of experiments involve the use of wrought Alloy 22 and one set of experiments involved the use of welded Alloy 22 samples.

(1) For the first set of tests, samples of wrought Alloy 22 (heat 2277-6-3181) (Table 1) were aged in air for $1 \mathrm{~h}, 10 \mathrm{~h}, 100 \mathrm{~h}$ and $1000 \mathrm{~h}$ at $900^{\circ} \mathrm{F}\left(482^{\circ} \mathrm{C}\right), 1100^{\circ} \mathrm{F}\left(593^{\circ} \mathrm{C}\right), 1300^{\circ} \mathrm{F}\left(704^{\circ} \mathrm{C}\right)$ and $1472^{\circ} \mathrm{F}$ $\left(800^{\circ} \mathrm{C}\right)$. These samples were used for electrochemical testing in $\mathrm{J}-13$ water $^{21}$ (Table 2) at $95^{\circ} \mathrm{C}$. The anodic behavior was determined using potentiodynamic polarization at a scan rate of $0.1 \mathrm{mV} / \mathrm{s}$ and the corrosion rate was evaluated using the AC Impedance technique. The impedance measurements were carried out potentiostatically by applying the corrosion potential with a sinusoidal perturbation of $10 \mathrm{mV}$ amplitude, in a descending frequency scanning between $1 \mathrm{kHz}$ and $1 \mathrm{mHz}$. The $\mathrm{J}-13$ electrolyte solution was in the naturally aerated condition; that is, a gas was not purged through the solution during the tests but the ingress of air above the solution level was not restricted. The reference electrode was saturated calomel [SCE], which at room temperature is $0.240 \mathrm{~V}$ more positive than the normal hydrogen electrode (NHE). The samples were prismatic (modified ASTM G 5) ) $^{22}$ and were prepared from 0.25 -inch (6.35 $\mathrm{mm}$ ) thick plates. The sample finish was produced with wet silicon carbide paper 1200 mesh. The total exposed area was approximately $5 \mathrm{~cm}^{2}$.

(2) In the second set of tests, wrought Alloy 22 samples (Heat 2277-8-3203) (Table 1) were aged in air for $10 \mathrm{~h}$ and $173 \mathrm{~h}$ at $700^{\circ} \mathrm{C}$. These samples were used for cyclic polarization tests in simulated acidified water (SAW) and simulated concentrated water $(\mathrm{SCW})$ solutions at $90^{\circ} \mathrm{C}$ (Table 2$) \cdot{ }^{20}$ During the anodic 
polarization, the scan rate was $0.167 \mathrm{mV} / \mathrm{s}$. The electrolyte solutions were purged with air before and during the tests. The reference electrode was silver-silver chloride [SSC], which at room temperature is approximately $0.197 \mathrm{~V}$ more positive than the NHE. The samples were disks (ASTM G 5), which were prepared from 0.125 -inch $(3.2 \mathrm{~mm})$ thick wrought sheet. They had a root mean square (RMS) roughness of $1 \mu$-inch and the total exposed area was approximately $0.7 \mathrm{~cm}^{2}$.

(3) For the third set of tests, two 0.125-inch thick sheets of Alloy 22 (Heat 2277-9-3237) (Table 1) were welded using Alloy 22 filler metal (Heat 2277-8-3277) (Table 1). After welding the plates were sliced in strips approximately 0.5 -inch wide. Each strip contained a weld seam in the center. The samples were aged for $0.25 \mathrm{~h}, 0.5 \mathrm{~h}, 1 \mathrm{~h}, 3 \mathrm{~h}, 6 \mathrm{~h}, 10 \mathrm{~h}, 30 \mathrm{~h}, 60 \mathrm{~h}, 100 \mathrm{~h}, 300 \mathrm{~h}, 600 \mathrm{~h}, 1000 \mathrm{~h}$ and $3,000 \mathrm{~h}$ at $900^{\circ} \mathrm{F}$ $\left(482^{\circ} \mathrm{C}\right), 1000^{\circ} \mathrm{F}\left(538^{\circ} \mathrm{C}\right), 1100^{\circ} \mathrm{F}\left(593^{\circ} \mathrm{C}\right), 1200^{\circ} \mathrm{F}\left(649^{\circ} \mathrm{C}\right), 1300^{\circ} \mathrm{F}\left(704^{\circ} \mathrm{C}\right)$ and $1400^{\circ} \mathrm{F}\left(760^{\circ} \mathrm{C}\right) . \mathrm{Ag}-$ ing was performed in air, and afterwards, the samples were rapid air-cooled. Most of the specimens were aged in the as-welded condition; however, one set of specimens was annealed at $2050^{\circ} \mathrm{F}\left(1121^{\circ} \mathrm{C}\right)$ for 20 minutes and water quenched before aging at $1200^{\circ} \mathrm{F}\left(649^{\circ} \mathrm{C}\right)$. The coupons for immersion testing contained by length approximately $1 / 3$ of weld material and $2 / 3$ of base material $(1 / 3$ at each side of the weld). Before testing the samples were cleaned by vapor blasting. Changes in the corrosion resistance were measured using standard immersion tests such as a boiling aqueous solution of $50 \%$ sulfuric acid $\left(\mathrm{H}_{2} \mathrm{SO}_{4}\right)+42 \mathrm{~g} / \mathrm{l}$ of ferric sulfate $\left(\mathrm{Fe}_{2}\left(\mathrm{SO}_{4}\right)_{3}\right)$ and boiling $2.5 \%$ hydrochloric acid $(\mathrm{HCl})$. The first test solution is also called the Streicher test or ASTM G $28 \mathrm{~A}$. This electrolyte boils at $120^{\circ} \mathrm{C}$ and is highly oxidizing. The second test solution is highly reducing, was carried out according to ASTM G 31 and it boils at approximately $101^{\circ} \mathrm{C} .^{22}$ The ASTM G $28 \mathrm{~A}$ test was carried out for $24 \mathrm{~h}$ and the boiling $\mathrm{HCl}$ test was carried out for a total time of $96 \mathrm{~h}$ (the electrolyte solution was changed every $24 \mathrm{~h}$ ). In these two tests, the solutions were open to the atmosphere through a condenser and a scrubber. Since the solutions were boiling, it is assumed that the amount of dissolved oxygen was insignificant.

\section{RESULTS AND DISCUSSION}

\section{Corrosion Rate and Passive Behavior in Multi-Component Waters}

$\mathrm{J}-13$ Water. Figure 1 shows the polarization curves of Alloy 22 in $\mathrm{J}-13$ water at $95^{\circ} \mathrm{C}$ for MA samples and for samples aged at $593^{\circ} \mathrm{C}$ and $800^{\circ} \mathrm{C}$ for $1000 \mathrm{~h}$. At potentials more anodic than the corrosion potential, the polarization curves of the three materials showed a passive region of potentials with a corresponding current density of approximately $2 \times 10^{-6} \mathrm{~A} / \mathrm{cm}^{2}$. Above this passive region, the three polarization curves showed an anodic peak followed by a second stage of passivation at a current density of $1 \mathrm{x}$ $10^{-5} \mathrm{~A} / \mathrm{cm}^{2}$. The anodic peak occurred between 0.2 and $0.4 \mathrm{~V}$ [SCE] and had a maximum current density of approximately $3 \times 10^{-5} \mathrm{~A} / \mathrm{cm}^{2}$. The breakdown potential occurred at approximately $0.5 \mathrm{~V}$ [SCE] for the sample aged at $800^{\circ} \mathrm{C}$ and at $0.65 \mathrm{~V}$ [SCE] for the MA sample and for the sample aged at $593^{\circ} \mathrm{C}$. The increase of current density at the breakdown potential is likely to be a result of oxygen evolution and transpassive oxidation of $\mathrm{Cr}$ III to Cr VI. Figure 1 shows that there is no apparent effect of alloy aging on the passive behavior of Alloy 22 in J-13 water. That is, practically the same potential-current relationships were obtained for MA material and for aged materials.

Figure 2 shows typical Bode diagrams obtained for Alloy 22 at the corrosion potential in J-13 water at $95^{\circ} \mathrm{C}$. These diagrams show typical capacitive behavior with a time distribution constant which can be represented by a constant phase element. ${ }^{23}$ Electrochemical impedance measurements were carried out for MA annealed and aged materials at different times and temperatures. An equation that represents a 
resistance-capacitance or RC equivalent circuit in parallel (Equation 1) was fitted to the experimental results

$$
Z=R_{\Omega}+\frac{R_{p}}{1+\left(j \omega R_{p} C\right)^{\beta}}
$$

where $R_{\Omega}$ represents the resistance of the electrolyte solution between the surface of the specimen and the end of the Luggin capillary; that is, $R_{\Omega}$ is the ohmic component determined at high frequency. $R_{p}$ represents the resistance determined at low frequency, which is associated to the resistance to polarization and is used to determine the corrosion rate of the alloy. $\beta$ is the dispersion parameter, which indicates the deviation from an ideal circuit or model $\mathrm{RC}, \mathrm{C}$ is the capacitance, $\omega$ is the angular frequency and $\mathrm{j}$ is the imaginary unit $(\sqrt{-1})$. Figure 3 shows the values of $R_{p}$ for all the tested specimens. Figure 3 also shows the corrosion rate (CR) of Alloy 22 calculated from the values of $R_{p}\left(\Omega . \mathrm{cm}^{2}\right)$ according to Equation 2.

$$
C R=\frac{E W}{\rho . F} \frac{b_{a} \cdot b_{c}}{2.303\left(b_{a}+b_{c}\right)} \frac{1}{R_{p}}=\frac{201.83}{R_{p}}\left(\frac{\mathrm{mm}}{\text { year }}\right)
$$

where EW is the equivalent weight of Alloy $22(24.76 \mathrm{~g} / \mathrm{mol}), \rho$ is the density of the alloy $\left(8.69 \mathrm{~g} / \mathrm{cm}^{3}\right)$, $b_{a}$ and $b_{c}$ are the anodic and cathodic Tafel slopes $(0.1 \mathrm{~V} /$ decade of current) and $\mathrm{F}$ is the Faraday constant $(96500 \mathrm{C} / \mathrm{mol})$. Figure 3 shows that, under the tested conditions, the corrosion rate of Alloy 22 was approximately $2 \times 10^{-4} \mathrm{~mm} /$ year and was not affected either by the aging temperature or the aging time. Similar results were also obtained in a solution containing $1000 \mathrm{ppm}$ of sodium chloride $(\mathrm{NaCl})$ represented by a full symbol. The scatter of the results in Figure 3 can be attributed to the low conductivity of the electrolyte solution $\left(\mathrm{R}_{\Omega}=500 \Omega . \mathrm{cm}^{2}\right)$ and the low current densities, which did not allow for measurements at frequencies below $1 \mathrm{mHz}$. In every case, the capacity value that was obtained from the fitting of the equation was in the order of $25 \mu \mathrm{F} . \mathrm{cm}^{-2}$, which is the value expected for the capacity of the double layer. This also indicates that the passivating layer is very thin and that the value of its capacitance is also high, similar to the value expected for the double layer. Therefore, the values of capacitance measured experimentally corresponded to a combination in series of the capacitance of the oxide and the capacitance of the double layer.

It has been shown that when Alloy 22 was aged for $1000 \mathrm{~h}$ at $800^{\circ} \mathrm{C}$, second detrimental phases formed not only at the grain boundary but also within the grains. Similarly, when Alloy 22 was aged at $593^{\circ} \mathrm{C}$ for $1000 \mathrm{~h}$, partial grain boundary precipitation and long range ordering occurred. ${ }^{18,19}$ It is likely that the precipitation of second phases, which greatly reduces the corrosion resistance of Alloy 22 in aggressive acidic solutions ${ }^{13}$ are not detrimental for the corrosion behavior of Alloy 22 in milder environments that could be more representative of the potential repository site.

Anodic Behavior in Concentrated Waters. Figure 4 shows the anodic polarization curves of Alloy 22 in aerated SAW at $90^{\circ} \mathrm{C}$. The polarization curves for MA material and for materials aged at $700^{\circ} \mathrm{C}$ for 10 $\mathrm{h}$ and for $173 \mathrm{~h}$ were similar. For all three aging conditions, the passive current density was approximately $4 \times 10^{-6} \mathrm{~A} / \mathrm{cm}^{2}$, and the breakdown potential was approximately $0.65 \mathrm{~V}$ (SSC). It is assumed that the increase of current at the breakdown potential was a combination of oxygen evolution and the transpassive oxidation of chromium ( $\mathrm{Cr}$ III to $\mathrm{Cr}$ VI). The Nernst equation for water of $\mathrm{pH} 2.8$ and $90^{\circ} \mathrm{C}$ 
predicts oxygen evolution of $10^{-6}$ atm at a potential in the vicinity of $0.7 \mathrm{~V}$ (SSC). A similar equation for $\mathrm{Cr}$ metal predicts the formation of $10^{-6} \mathrm{M}$ chromate $\left(\mathrm{CrO}_{4}{ }^{2-}\right)$ species $(\mathrm{Cr} \mathrm{VI})$ from $\mathrm{Cr}$ III species at a potential of $0.54 \mathrm{~V}$ (SSC). ${ }^{24}$ Both of these values are in the vicinity of the breakdown potential of $0.65 \mathrm{~V}$ (SSC) reported above. For all three materials, the reverse curve of the cyclic polarization was similar or higher than the forward curve (Figure 4), indicating that Alloy 22 was not susceptible to localized corrosion in any of the tested conditions. Observation of the specimens after testing showed only general transpassive dissolution and the absence of crevice or pitting corrosion.

Figure 5 shows the anodic polarization curves of Alloy 22 in aerated SCW at $90^{\circ} \mathrm{C}$. The polarization curves were similar for MA material and for materials aged at $700^{\circ} \mathrm{C}$ for $10 \mathrm{~h}$ and for $173 \mathrm{~h}$. Each anodic polarization curve in Figure 5 had four characteristic regions. The first region was a passive current of approximately $1 \times 10^{-5} \mathrm{~A} / \mathrm{cm}^{2}$, followed by a second region or anodic peak between the potentials of 0.2 $\mathrm{V}$ and $0.4 \mathrm{~V}$ (SSC). The maximum current density of this anodic peak was approximately $1 \times 10^{-3}$ $\mathrm{A} / \mathrm{cm}^{2}$. The potential of the apex of the peak seemed to decrease slightly $(\sim 50 \mathrm{mV})$ as the aging time increased. The third region was a second passive segment at a current density of approximately $1 \times 10^{-4}$ $\mathrm{A} / \mathrm{cm}^{2}$. The fourth was the transpassive region and it occurred at above approximately $0.7 \mathrm{~V}$ (SSC). For all three materials, the reverse curve was similar to the forward curve (Figure 5), indicating that Alloy 22 was not susceptible to localized corrosion in any of the tested conditions. Observation of the specimens after testing showed only general transpassive dissolution and absence of crevice and/or pitting corrosion.

Aging of wrought Alloy 22 for $10 \mathrm{~h}$ at $700^{\circ} \mathrm{C}$ produces partial grain boundary precipitation of detrimental second phases and aging for $173 \mathrm{~h}$ at $700^{\circ} \mathrm{C}$ produces full grain boundary coverage of this second phase. $^{18,19}$ It has been shown that the presence of secondary phases in Alloy 22 increased its critical current for passivation as well as the anodic passive current when anodically polarized in $1 \mathrm{M}$ hydrochloric acid $(\mathrm{HCl})$ solution at $66^{\circ} \mathrm{C} .^{25}$ However, Figures 4 and 5 show that the presence of these secondary phases at the grain boundary do not affect the anodic behavior of Alloy 22 in concentrated multi component aqueous solutions that could be relevant to the potential repository site.

The anodic peak in Alloy 22 was only observed in near neutral and alkaline solutions (Figures 1 and 5) but it was not observed in an acidic solution (Figure 4). The maximum current density of this peak seemed to be approximately two orders of magnitude lower for a dilute solution (Figure 1) than for a concentrated solution of higher $\mathrm{pH}$ (Figure 5). Figure 1 and 5 also show that the current density in the second region of passivity (above the anodic peak) was one order of magnitude higher than the current density in the passive region below the peak. The origin and nature of this anodic peak are not fully understood yet; however, previous researchers attributed it to the oxidation of Mo IV to Mo VI. ${ }^{26,27}$

Immersion tests of welded material in aggressive acidic solutions

Table 3 shows the corrosion rates of welded Alloy 22 in ASTM G 28 A and boiling $2.5 \% \mathrm{HCl}$ solutions for six aging temperatures and thirteen different aging times. Figures 6 shows that the corrosion rate of aged Alloy 22 in ASTM G 28 A solution (oxidizing) increased gradually as the aging time and the aging temperature increased (for $\mathrm{T} \geq 538^{\circ} \mathrm{C}$ ). For samples aged at $482^{\circ} \mathrm{C}$ the corrosion rate remained the same, even after aging for $3,000 \mathrm{~h}$. For samples aged at $760^{\circ} \mathrm{C}$ and $704^{\circ} \mathrm{C}$, the corrosion rate seemed to reach a plateau for aging times higher than $100 \mathrm{~h}$. Observation of the tested coupons in the ASTM G 28 A solution showed preferential corrosion at the grain boundaries. At higher aging times deeper grain boundary 
attack was observed, and in certain testing conditions some grains fell away because they became completely detached from the samples.

Figure 7 shows that the corrosion rate in boiling $2.5 \% \mathrm{HCl}$ solution increased approximately three times after a certain threshold aging time at each temperature. The higher the temperature the lower the threshold time. Corrosion data for $760^{\circ} \mathrm{C}$ and $704^{\circ} \mathrm{C}$ shows that after this initial sudden increase in the corrosion rate, it remained approximately constant as the aging time increased; however, it increased again after a second threshold time. For samples aged at $482^{\circ} \mathrm{C}$ the corrosion rate remained the same, even after aging for 3,000 h. Observation of the tested coupons in boiling $2.5 \% \mathrm{HCl}$ solution showed preferential intergranular attack which became deeper and wider as the aging time increased. At aging times of 1000 $h$ and higher, preferential corrosion attack at twins inside the grains was observed.

Figures 8 and 9 show the effect of annealing on the corrosion behavior of Alloy 22 welded coupons. Figure 8 shows the corrosion rate in ASTM G 28 A for a series of coupons that were aged in the as welded conditions and also for coupons that were annealed at $1121^{\circ} \mathrm{C}$ for 20 minutes and then water quenched before aging. For aging times shorter that $10 \mathrm{~h}$ the corrosion rate of the annealed coupons was higher than of those that were in the as-welded conditions (Figure 8). For aging times of $10 \mathrm{~h}$ and $30 \mathrm{~h}$, the corrosion rate of both types of coupons was the same; however, for aging times of $60 \mathrm{~h}$ to $1000 \mathrm{~h}$, the corrosion rate of the annealed coupons was lower than the corrosion rate of the as-welded coupons. This behavior is not fully understood. On the other hand, Figure 9 shows that in boiling $2.5 \% \mathrm{HCl}$ solution, the corrosion rate of the annealed and aged coupons was always lower than the corrosion rate of the as-welded and aged coupons.

Figures 10 and 11 show the effect of welding on the corrosion rate of Alloy 22. Most of the corrosion rates of wrought Alloy 22 were published before. ${ }^{13,27}$ Figure 10 shows the corrosion rate in ASTM G 28 A for wrought and as-welded coupons at two aging temperatures $\left(760^{\circ} \mathrm{C}\right.$ and $\left.538^{\circ} \mathrm{C}\right)$ as a function of aging time. For all aging times, the corrosion rate of welded coupons was always higher than the corrosion rate of wrought coupons. For example, at the aging temperature of $760^{\circ} \mathrm{C}$ and at the aging time of $10 \mathrm{~h}$, the corrosion rate of the welded coupons was approximately two times the corrosion rate of the wrought coupons. Figure 11 shows the corrosion rate in boiling $2.5 \% \mathrm{HCl}$ solution for wrought and as-welded coupons at two aging temperatures $\left(760^{\circ} \mathrm{C}\right.$ and $\left.538^{\circ} \mathrm{C}\right)$ as a function of aging time. For all aging times, the corrosion rate of welded coupons was always higher than the corrosion rate of wrought coupons. For the shorter aging times (up to 3-6 h) the corrosion rate of the welded coupons was approximately three times the corrosion rate of the wrought coupons; however, for aging times of $6 \mathrm{~h}$ and longer, the difference in the corrosion rate was smaller.

Figure 12 shows the time necessary at each aging temperature for Alloy 22 to reach a corrosion rate of $80 \mathrm{mpy}(\sim 2 \mathrm{~mm} /$ year) in ASTM G $28 \mathrm{~A}$, both for wrought and welded materials. Figure 12 shows that at each aging temperature, a shorter aging time is required for the welded material to reach the threshold corrosion rate of 80 mpy (Figures 10). Figure 12 shows that the Arrhenius slopes for both materials are the same, that is, the degradation of the welded material started earlier than the degradation for the wrought material; however, the degradation rate was the same. The slope of both curves in Figure 12 could be equated to $-Q_{a p} / R$, where $Q_{a p}$ is the apparent activation energy for the aging process in Alloy 22 and $\mathrm{R}$ is the gas constant. Calculations show that this apparent activation energy, as determined by corrosion testing in oxidizing conditions (ASTM G $28 \mathrm{~A}$ ) was $261 \mathrm{~kJ} / \mathrm{mol}$ for wrought material and 262 $\mathrm{kJ} / \mathrm{mol}$ for welded material. A similar plot for corrosion in boiling $2.5 \% \mathrm{HCl}$ (reducing conditions) showed $\mathrm{Q}_{\mathrm{ap}}=244 \mathrm{~kJ} / \mathrm{mol}$ for wrought material and $\mathrm{Q}_{\mathrm{ap}}=306 \mathrm{~kJ} / \mathrm{mol}$ for welded material. For the $2.5 \%$ 
$\mathrm{HCl}$ solution, the curves for both materials were not parallel as in the case of the ASTM G 28 A solution. Assuming that the aging mechanism remains the same at the lower temperatures, Figure 12 shows that if the Arrhenius relationship is extrapolated to aging temperatures of $300^{\circ} \mathrm{C}$, aging times higher than 10,000 years would be necessary for Alloy 22 to show a degradation corresponding to a corrosion rate of 80 mpy.

\section{CONCLUSIONS}

(1) The corrosion rate of MA and aged Alloy 22 in simulated $\mathrm{J}-13$ water at $95^{\circ} \mathrm{C}$ was in the order of $0.0002 \mathrm{~mm} /$ year and it did not change as a function of aging temperature and aging time.

(2) Cyclic polarization curves of MA and aged Alloy 22 in aerated SAW and SCW multi component solutions at $90^{\circ} \mathrm{C}$ were the same.

(3) When anodically polarized in near neutral and alkaline solutions, both MA and aged Alloy 22 showed an anodic peak between $0.2 \mathrm{~V}$ and $0.4 \mathrm{~V}$ (SSC). This peak was not evident in acidic solutions.

(4) When welded Alloy 22 coupons were aged at temperatures between $538^{\circ} \mathrm{C}$ and $760^{\circ} \mathrm{C}$, the corrosion rate in oxidizing (ASTM G $28 \mathrm{~A}$ ) and reducing (boiling $2.5 \% \mathrm{HCl}$ ) solutions increased both with the aging temperature and aging time.

(5) For the same aging temperature and aging time, the corrosion rate of welded Alloy 22 was higher than the corrosion rate of wrought material.

(6) The corrosion degradation rate of Alloy 22 due to high temperature aging was the same for wrought and welded materials.

\section{ACKNOWLEDGMENTS}

The authors appreciate the efforts of Michael Newburn, Jim Barnes, Mark Britton, Natalie Koon and Joe Gibson at Haynes International Inc. Part of this work was performed under the auspices of the U. S. Department of Energy by University of California Lawrence Livermore National Laboratory under contract $\mathrm{N}^{\circ}$ W-7405-Eng-48. This work is supported in part by Yucca Mountain Site Characterization Project.

\section{DISCLAIMER}

This document was prepared as an account of work sponsored by an agency of the United States Government. Neither the United States Government nor the University of California nor any of their employees, makes any warranty, express or implied, or assumes any legal liability or responsibility for the accuracy, completeness, or usefulness of any information, apparatus, product, or process disclosed, or represents that its use would not infringe privately owned rights. Reference herein to any specific commercial product, process, or service by trade name, trademark, manufacturer, or otherwise, does not necessarily constitute or imply its endorsement, recommendation, or favoring by the United States Government or the University of California. The views and opinions of authors expressed herein do not neces- 
sarily state or reflect those of the United States Government or the University of California, and shall not be used for advertising or product endorsement purposes.

\section{REFERENCES}

1. P. E. Manning, J. D. Schöbel, Werkstoffe und Korrosion, 37, (1986): p 137.

2. A. I. Asphahani, The Arabian Journal for Science and Engineering, Volume 14, Number 2, (1989): p. 317.

3. S. J. Lukezich, The Corrosion Behavior of Ni-Base High Performance Alloys in Simulated Repository Environments, MS Thesis, The Ohio State University, 1989.

4. R. B. Rebak, in Proceedings of the Symposium on Passivity and Its Breakdown, Volume 97-26 (Pennington, NJ: The Electrochemical Society, 1998): p. 1001

5. A. K. Roy, D. L. Fleming, B. Y. Lum, MP, March, (1998): p. 54.

6. R. B. Rebak and N. E. Koon, Corrosion/98, Paper 153, (Houston, TX: NACE International, 1998).

7. K. A. Gruss, G. A. Cragnolino, D. S. Dunn, N. Sridhar, Corrosion/98, Paper 149 (Houston, TX: NACE International, 1998).

8. R. B. Rebak, P. Crook, in Critical Factors in Localized Corrosion III, Volume PV 98-17 (Pennington, NJ: The Electrochemical Society, 1999): p. 289.

9. R. B. Rebak, N. E. Koon, J. P. Cotner, P. Crook, in Passivity and Localized Corrosion, Volume PV 99-27 (Pennington, NJ: The Electrochemical Society, 1999): p. 473

10. D. S. Dunn, G. A. Cragnolino, N Sridhar, in Scientific Basis for Nuclear Waste Management XXII, Vol. 556 (Warrendale, PA: Materials Research Society, 1999): p. 879.

11. B. A. Kehler, G. O. Ilevbare, J. R. Scully, Corrosion/2000, Paper 182 (Houston, TX: NACE International, 2000).

12. D. S. Dunn, G. A. Cragnolino, N Sridhar, in Scientific Basis for Nuclear Waste Management XXIII, Vol. 608 (Warrendale, PA: Materials Research Society, 2000): p. 89.

13. R. B. Rebak, N. E. Koon, J. R. Dillman, P. Crook, T. S. Edgecumbe Summers, Corrosion/2000, Paper 181 (Houston, TX: NACE International, 2000).

14. S. J. Matthews in Proceedings of the Third International Conference on Superalloys, (Baton Rouge, LA: Claitor's Publishing Division, 1976): p. 215.

15. U. L. Heubner, E. Altpeter, M. B. Rockel and E. Wallis, Corrosion, 45 (1989): p. 249.

16. H. M. Tawancy, J. Mater. Sci., 31 (1996): p. 3929.

17. T. S. Edgecumbe Summers, M. A. Wall, M. Kumar, S. J. Matthews, R. B. Rebak, in Scientific Basis for Nuclear Waste Management XXII, Vol. 556 (Warrendale, PA: Materials Research Society, 1999): p. 919.

18. R. B. Rebak, T. S. Edgecumbe Summers, R. M. Carranza, in Scientific Basis for Nuclear Waste Management XXIII, Vol. 608 (Warrendale, PA: Materials Research Society, 2000): p. 109.

19. T. S. Edgecumbe Summers, T. Shen, R. B. Rebak in Ageing Studies and Lifetime Extension of Materials, (New York, NY: Kluwer Academic/Plenum Publisher, 2001): p. 507

20. N. D. Rosenberg, G. E. Gdowski and K. G. Knauss, Applied Geochemistry, 16 (2001), p. 1231

21. J. E. Harrar, J. F. Carley, W. F. Isherwood and E. Raber, Report on the Committee to Review the use of J-13 Well Water in Nevada Nuclear Waste Storage Investigations, LLNL UCID 21867 (University of California, January 1990).

22. Annual Book of ASTM Standards, Volume 03.02 (West Conshohocken, PA: American Society for Testing and Materials, 2001). 
23. J. Ross Macdonald, Impedance Spectroscopy - Emphasizing Solid Materials and Systems, (New York, NY: John Wiley and Sons, 1987).

24. M. Pourbaix, Atlas of Electrochemical Equilibria in Aqueous Solutions (Houston, TX: NACE International, 1974).

25. R. B. Rebak, N. E. Koon, P. Crook, in Electrochemical Approach to Selected Corrosion and Corrosion Control Studies, Number 28 (London, UK: The Institute of Materials, 2000): p. 245

26. J. Postlethwaite, R. J. Scoular and M. H. Dobbin, Corrosion, 44 (1988): p. 199.

27. G. O. Ilevbare, T. Lian and J. C. Farmer, "Environmental Considerations in the Studies of Corrosion Resistant Alloys for High-Level Radioactive Waste Containment," CORROSION/02, Paper no. 539 (Houston, TX: NACE International, 2002).

TABLE 1

CHEMICAL COMPOSITION OF THE STUDIED ALLOY 22 HEATS (WT\%)

\begin{tabular}{lcccc}
\hline Element & $2277-6-3181$ & $2277-8-3203$ & $2277-9-3237$ & $2277-8-3277$ \\
\hline $\mathrm{C}$ & 0.004 & 0.002 & 0.0047 & 0.0066 \\
$\mathrm{Co}$ & 1.11 & 1.82 & 0.9 & 1.1 \\
$\mathrm{Cr}$ & 21.59 & 21.3 & 21.26 & 21.58 \\
$\mathrm{Fe}$ & 3.9 & 4.0 & 3.97 & 4.17 \\
$\mathrm{Mn}$ & 0.28 & 0.19 & 0.25 & 0.25 \\
$\mathrm{Mo}$ & 13.64 & 13.08 & 13.15 & 13.29 \\
$\mathrm{Ni}$ & $\sim 56.3$ & $\sim 56.5$ & $\sim 57.4$ & $\sim 56.3$ \\
$\mathrm{P}$ & 0.013 & $<0.005$ & 0.01 & 0.005 \\
$\mathrm{~S}$ & $<0.001$ & 0.008 & 0.003 & 0.0031 \\
$\mathrm{~V}$ & 0.17 & 0.14 & 0.21 & 0.18 \\
$\mathrm{~W}$ & 3.03 & 2.93 & 2.90 & 3.18 \\
\hline
\end{tabular}

TABLE 2

CHEMICAL COMPOSITION OF MULTIIONIC ELECTROLYTE SOLUTIONS (mg/L)

\begin{tabular}{lccc}
\hline Ion & $\mathrm{J}-13, \mathrm{pH} 7.4$ & $\mathrm{SCW}, \mathrm{pH} 10.3$ & $\mathrm{SAW}, \mathrm{pH} 2.8$ \\
\hline $\mathrm{K}^{+}$ & 5.04 & 3400 & 3400 \\
$\mathrm{Na}^{+}$ & 45.8 & 40,900 & 40,900 \\
$\mathrm{Mg}^{2+}$ & 2.01 & $<1$ & 1000 \\
$\mathrm{Ca}^{2+}$ & 13 & $<1$ & 1000 \\
$\mathrm{~F}^{-}$ & 2.18 & 1400 & 0 \\
$\mathrm{Cl}^{-}$ & 7.14 & 6700 & 24,250 \\
$\mathrm{NO}_{3}{ }^{-}$ & 8.78 & 6400 & 23,000 \\
$\mathrm{SO}_{4}{ }^{2-}$ & 18.4 & 16,700 & 38,600 \\
$\mathrm{HCO}_{3}^{-}$ & 128.9 & 70,000 & 0 \\
$\mathrm{SiO}_{3}{ }^{-2}$ & 61.1 & $\sim 40$ & $\sim 40$ \\
& & & \\
\hline
\end{tabular}


TABLE 3

CORROSION RATE OF WELDED AND WELDED + AGED ALLOY 22 IN MPY

To convert mpy to $\mathrm{mm} /$ year multiply by 0.0254

\begin{tabular}{|c|c|c|c|}
\hline Aging Temp. ${ }^{\circ} \mathrm{C}\left({ }^{\circ} \mathrm{F}\right)$ & Aging Time, $\mathrm{h}$ & ASTM G $28 \mathrm{~A}$ & $2.5 \% \mathrm{HCl}$, boiling \\
\hline Ambient & Variable & $41.3,44.1$ & 214,215 \\
\hline \multirow[t]{12}{*}{$760(1400)$} & 0.25 & $65.2,65.1$ & 611,602 \\
\hline & 0.5 & $75.9,75.7$ & 691,697 \\
\hline & 1 & $97,97.5$ & 759,737 \\
\hline & 3 & 192,175 & 746,745 \\
\hline & 6 & 280,246 & 715,704 \\
\hline & 10 & 321,337 & 711,710 \\
\hline & 30 & 555,609 & 701,715 \\
\hline & 60 & 609,720 & 792,755 \\
\hline & 100 & 719,721 & 806,769 \\
\hline & 300 & 958,932 & 881,868 \\
\hline & 600 & 1115,1074 & 910,862 \\
\hline & 1000 & 1181,1162 & 856,853 \\
\hline \multirow[t]{12}{*}{$704(1300)$} & 0.25 & $39.1,38.8$ & 247,257 \\
\hline & 0.5 & $44.7,49.8$ & 290,295 \\
\hline & 1 & $50.6,53.5$ & 324,329 \\
\hline & 3 & $73.4,51.2$ & 511,504 \\
\hline & 6 & 119,124 & 705,690 \\
\hline & 10 & 123,126 & 722,708 \\
\hline & 30 & 300,304 & 704,725 \\
\hline & 60 & 602,611 & 683,686 \\
\hline & 100 & 732,742 & 670,690 \\
\hline & 300 & 1318,1385 & 758,784 \\
\hline & 600 & 1423,1424 & 850,848 \\
\hline & 1,000 & 1130,1123 & 901,916 \\
\hline \multirow[t]{11}{*}{$649(1200)$} & 0.5 & $40,38.6$ & 198,196 \\
\hline & 1 & $40.7,39.8$ & 212,199 \\
\hline & 3 & $40.7,39.6$ & 214,213 \\
\hline & 6 & $40.4,42.3$ & 243,238 \\
\hline & 10 & $57.1,56.3$ & 249,280 \\
\hline & 30 & $79.2,74.9$ & 427,390 \\
\hline & 60 & $97.2,92.2$ & 597,628 \\
\hline & 100 & 119,114 & 670,642 \\
\hline & 300 & 366,348 & 692,682 \\
\hline & 600 & 896,1221 & 695,675 \\
\hline & 1,000 & 2064,2077 & 728,709 \\
\hline
\end{tabular}


TABLE 3, CONTINUED

\begin{tabular}{|c|c|c|c|}
\hline $649(1200)$ & 0 & $58.3,63.5$ & 147,147 \\
\hline ASW + Annealed & 0.5 & $70.2,73.4$ & 150,146 \\
\hline at $2050^{\circ} \mathrm{F}\left(1121^{\circ} \mathrm{C}\right)$ & 1 & $55.7,51.4$ & 156,156 \\
\hline for 20 Minutes & 3 & $66.7,64.8$ & 158,152 \\
\hline + Water Quenched & 6 & $45.4,49.1$ & 154,170 \\
\hline \multirow[t]{7}{*}{ Before Aging } & 10 & $56.1,62.3$ & 166,153 \\
\hline & 30 & $69.5,71.6$ & 222,205 \\
\hline & 60 & $68.6,76.3$ & 493,502 \\
\hline & 100 & $70.5,75.8$ & 529,545 \\
\hline & 300 & 207,165 & 609,600 \\
\hline & 600 & 289,307 & 573,615 \\
\hline & 1,000 & 447,567 & 608,631 \\
\hline \multirow[t]{11}{*}{$593(1100)$} & 0.5 & $49,49.8$ & 207,207 \\
\hline & 1 & $46.2,46.2$ & 198,205 \\
\hline & 3 & $46.6,46.5$ & 200,202 \\
\hline & 6 & $45.3,47.4$ & 214,206 \\
\hline & 10 & $47.6,48.4$ & 225,214 \\
\hline & 30 & $48.6,49.5$ & 201,209 \\
\hline & 60 & $47.5,43.8$ & 210,214 \\
\hline & 100 & $52.8,54$ & 220,217 \\
\hline & 300 & $68.7,71.5$ & 322,319 \\
\hline & 600 & $98.8,92.7$ & 494,504 \\
\hline & 1,000 & 120,118 & 586,585 \\
\hline \multirow[t]{11}{*}{$538(1000)$} & 1 & $52.1,53.1$ & 245,260 \\
\hline & 3 & $51.8,50.5$ & 253,253 \\
\hline & 6 & $50,53.2$ & 253,262 \\
\hline & 10 & $53.7,55.8$ & 180,189 \\
\hline & 30 & $47.4,45.6$ & 189,193 \\
\hline & 60 & $38.7,39.8$ & 200,196 \\
\hline & 100 & $44.5,44$ & 202,184 \\
\hline & 300 & $32.4,36.2$ & 222,230 \\
\hline & 600 & $46.1,45.4$ & 259,254 \\
\hline & 1,000 & $48.1,48.5$ & 261,288 \\
\hline & 3,000 & $87,88.5$ & 473,487 \\
\hline \multirow[t]{11}{*}{$482(900)$} & 1 & $54.7,55$ & 206,202 \\
\hline & 3 & $56.4,53.2$ & 196,195 \\
\hline & 6 & $52.5,53.7$ & 202,191 \\
\hline & 10 & $53.1,52.7$ & 201,193 \\
\hline & 30 & $50.9,50.5$ & 190,187 \\
\hline & 60 & $40.5,41.5$ & 189,183 \\
\hline & 100 & $38.8,42.4$ & 199,189 \\
\hline & 300 & $39.8,39.5$ & 188,192 \\
\hline & 600 & $44.8,44.4$ & 188,192 \\
\hline & 1,000 & $45.6,45.4$ & 233,255 \\
\hline & 3,000 & $34.1,35.3$ & 179,179 \\
\hline
\end{tabular}




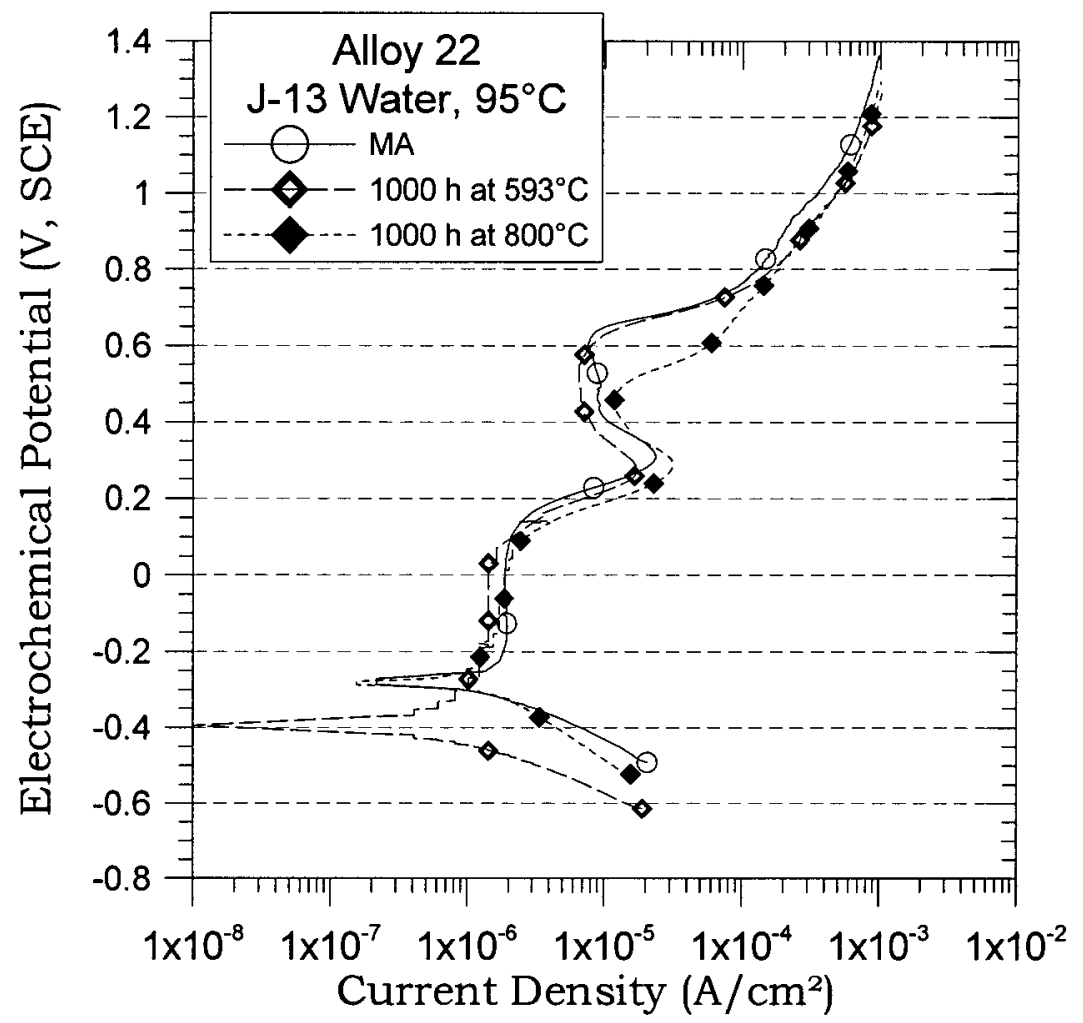

FIGURE 1: Polarization curves of Alloy 22 in J-13 Water at $95^{\circ} \mathrm{C}$

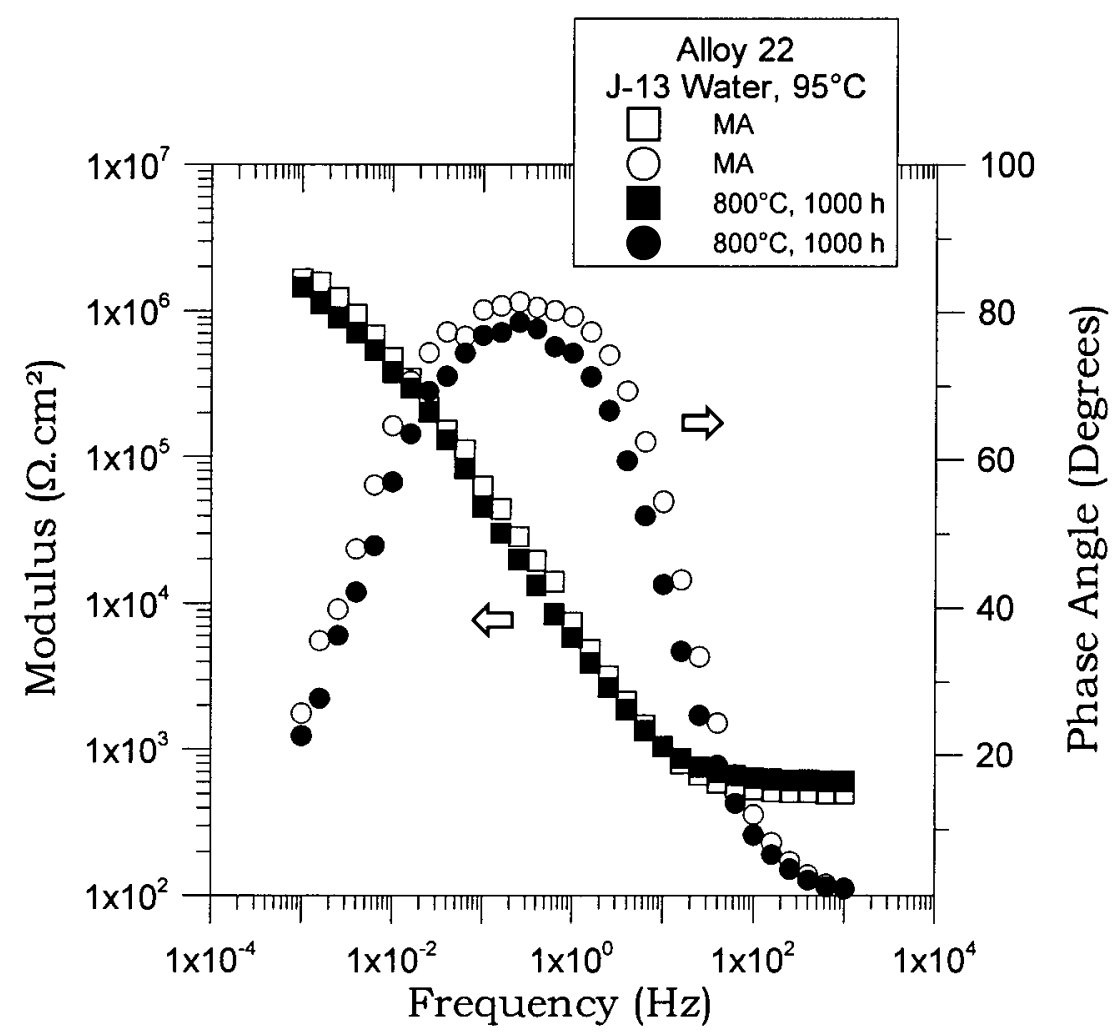

FIGURE 2: Typical Bode diagrams for Alloy 22 in J-13 Water at $95^{\circ} \mathrm{C}$. 


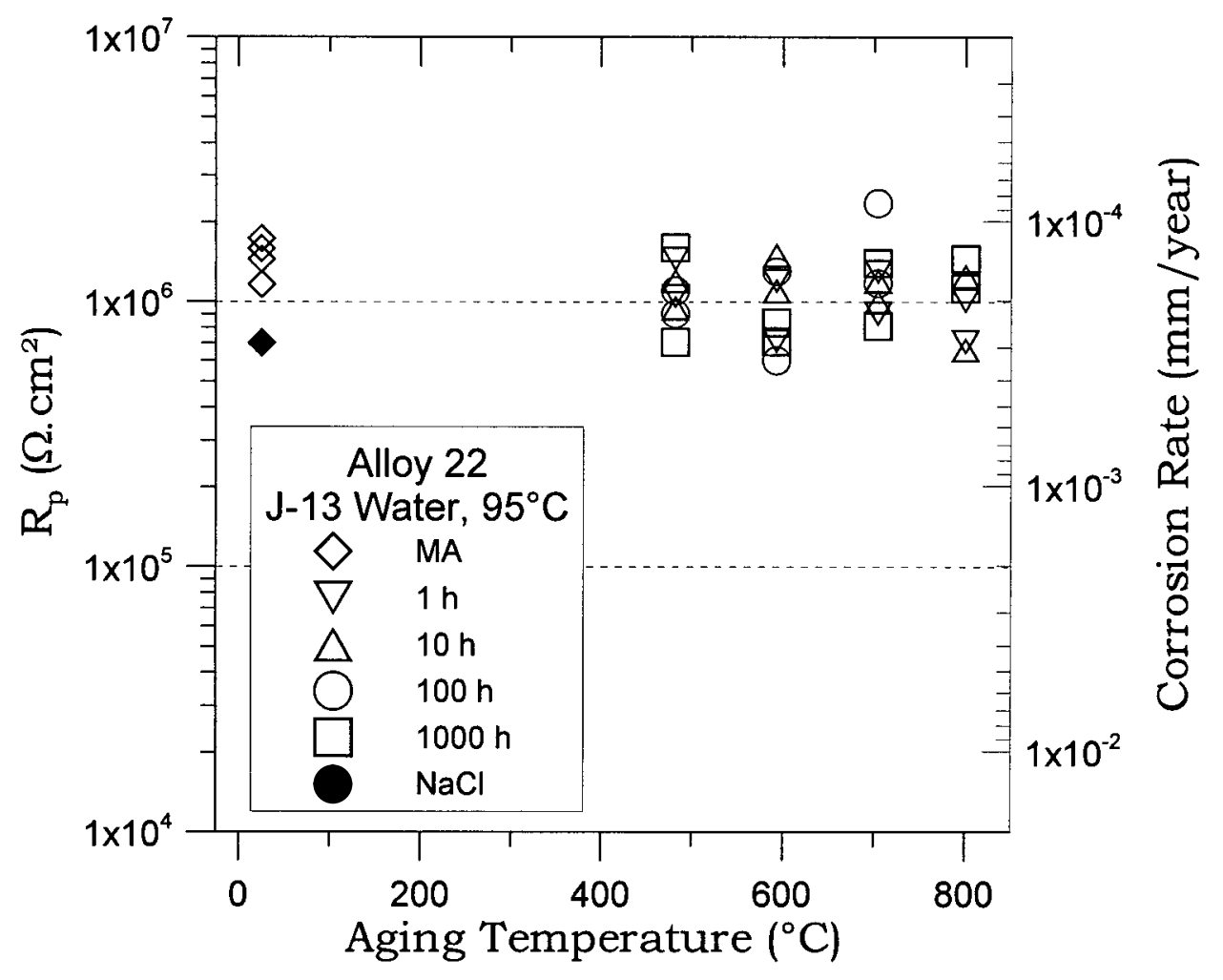

FIGURE 3: Corrosion rate of Alloy 22 in J-13 water as a function of aging temperature and aging time.

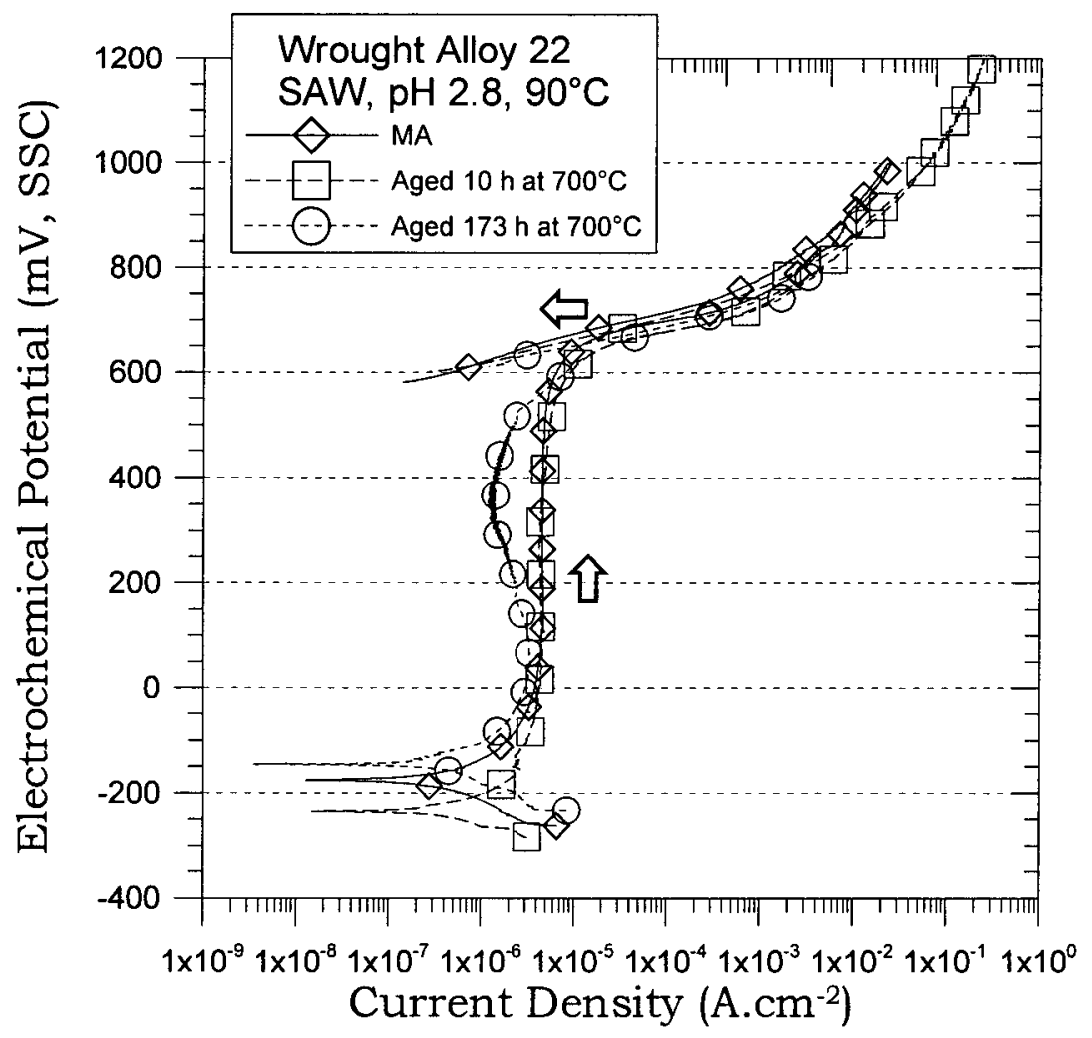

FIGURE 4: Cyclic polarization curve of Alloy 22 in SAW at $90^{\circ} \mathrm{C}$. 


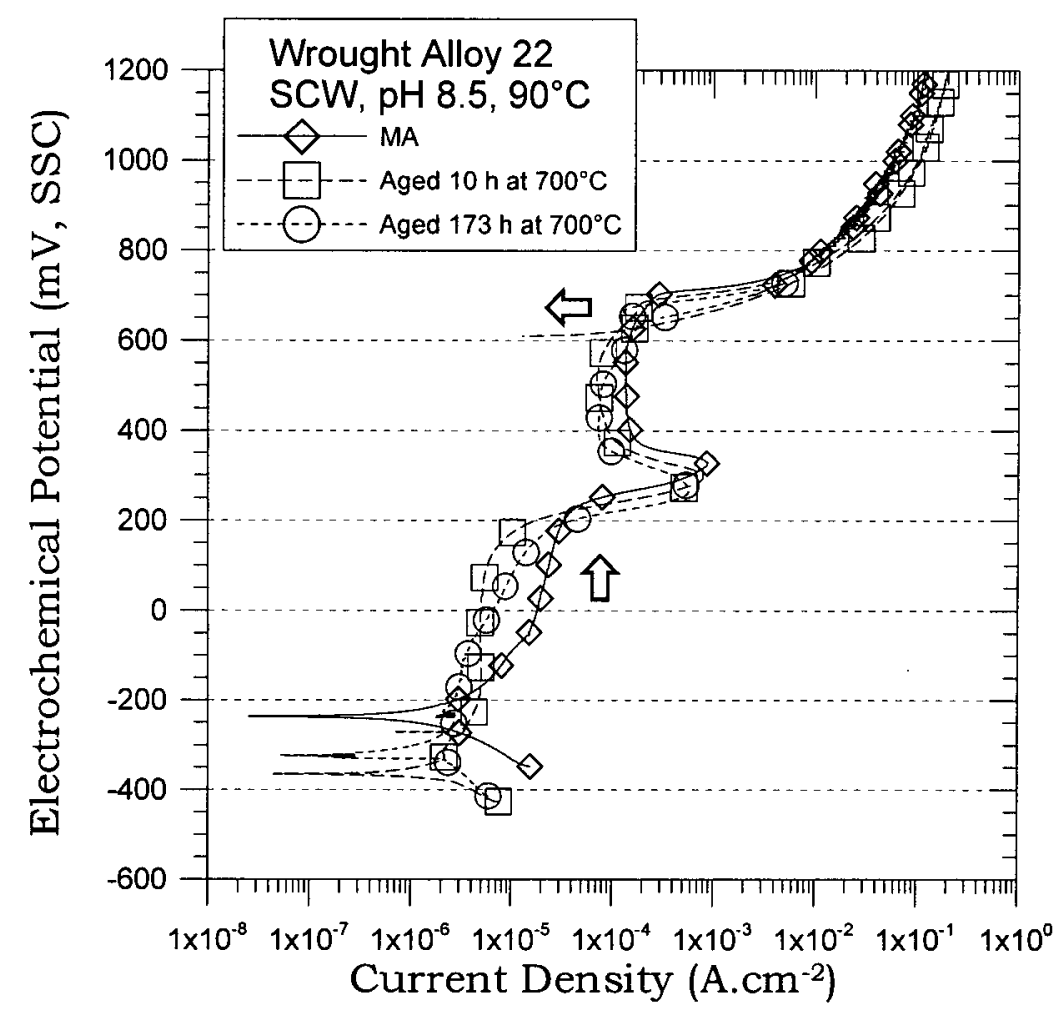

FIGURE 5: Cyclic polarization curves of Alloy 22 in SCW at $90^{\circ} \mathrm{C}$.

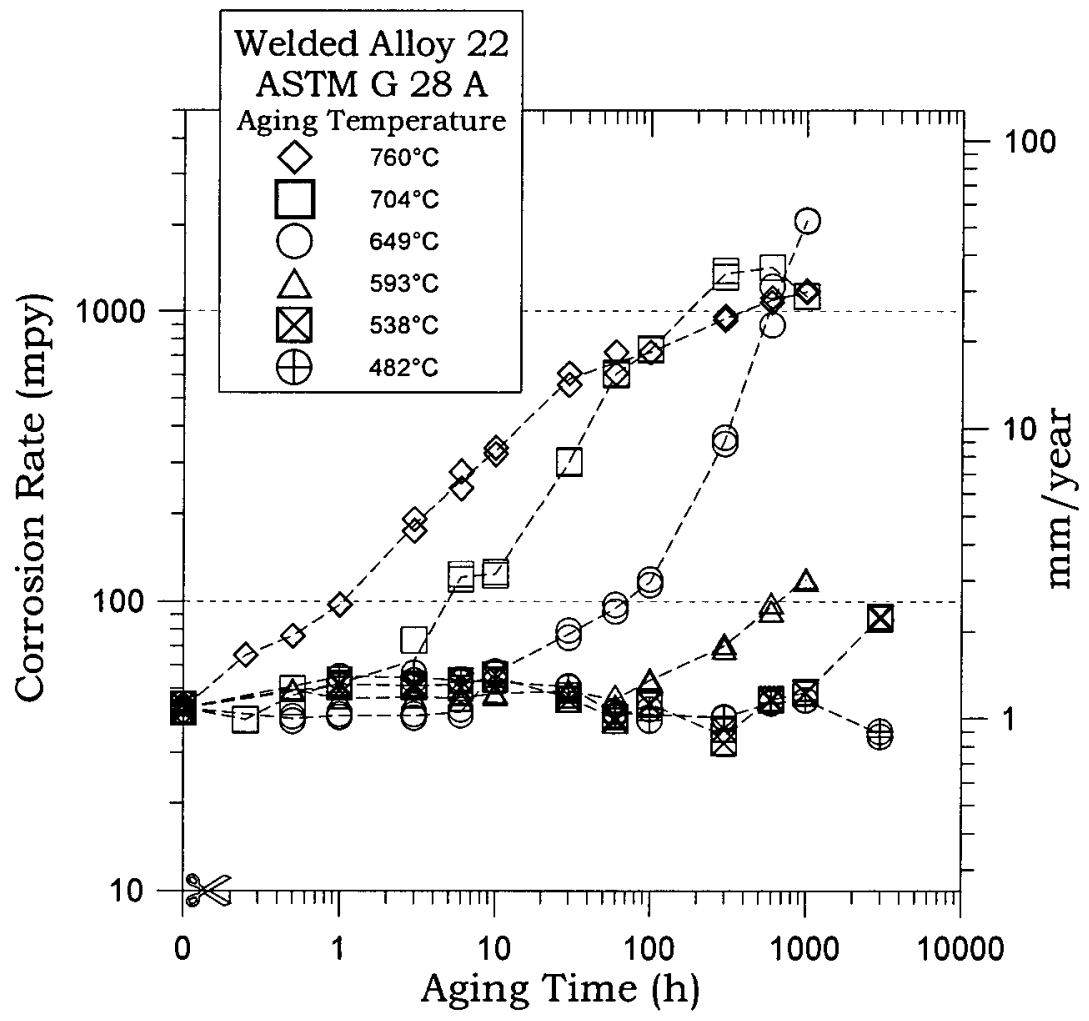

FIGURE 6: Corrosion rate of As-Welded and Welded + aged Alloy 22 in ASTM G 28 A solution. 


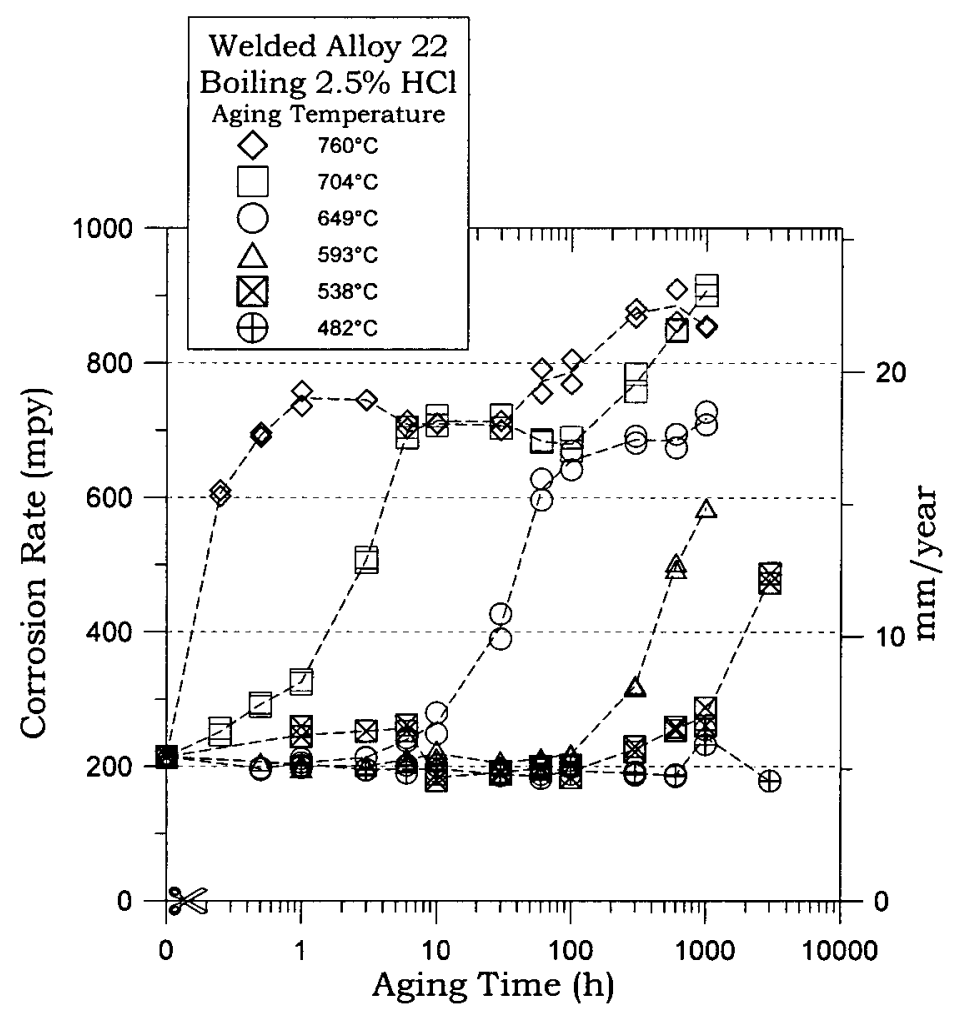

FIGURE 7: Corrosion rate of As-Welded and Welded + aged Alloy 22 in boiling $2.5 \% \mathrm{HCl}$ solution.

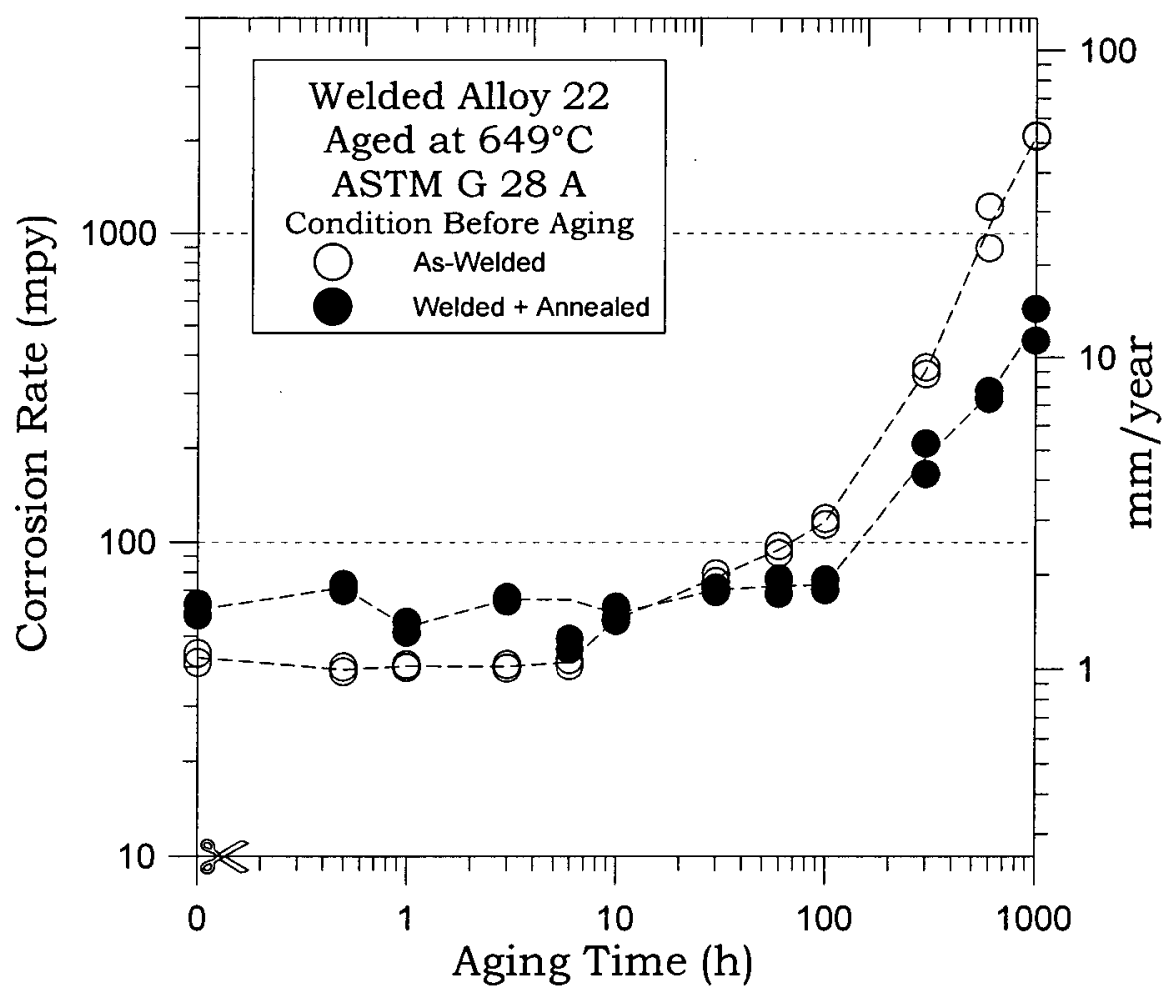

FIGURE 8: Corrosion rate in ASTM G 28 A solution of As-Welded and Welded + annealed Alloy 22 aged at $649^{\circ} \mathrm{C}$. 


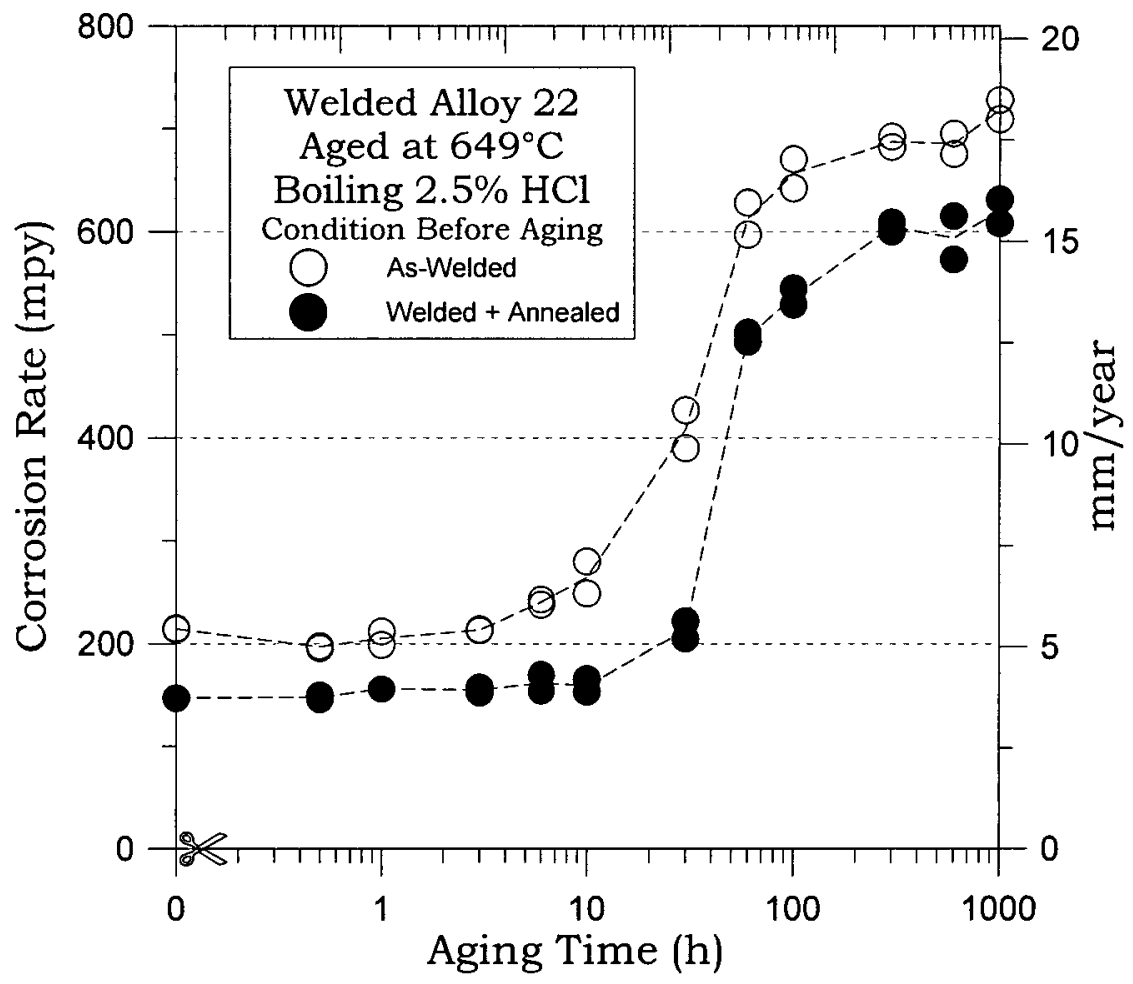

FIGURE 9: Boiling $2.5 \% \mathrm{HCl}$ solution of As-Welded and Welded + annealed Alloy 22 aged at $649^{\circ} \mathrm{C}$.

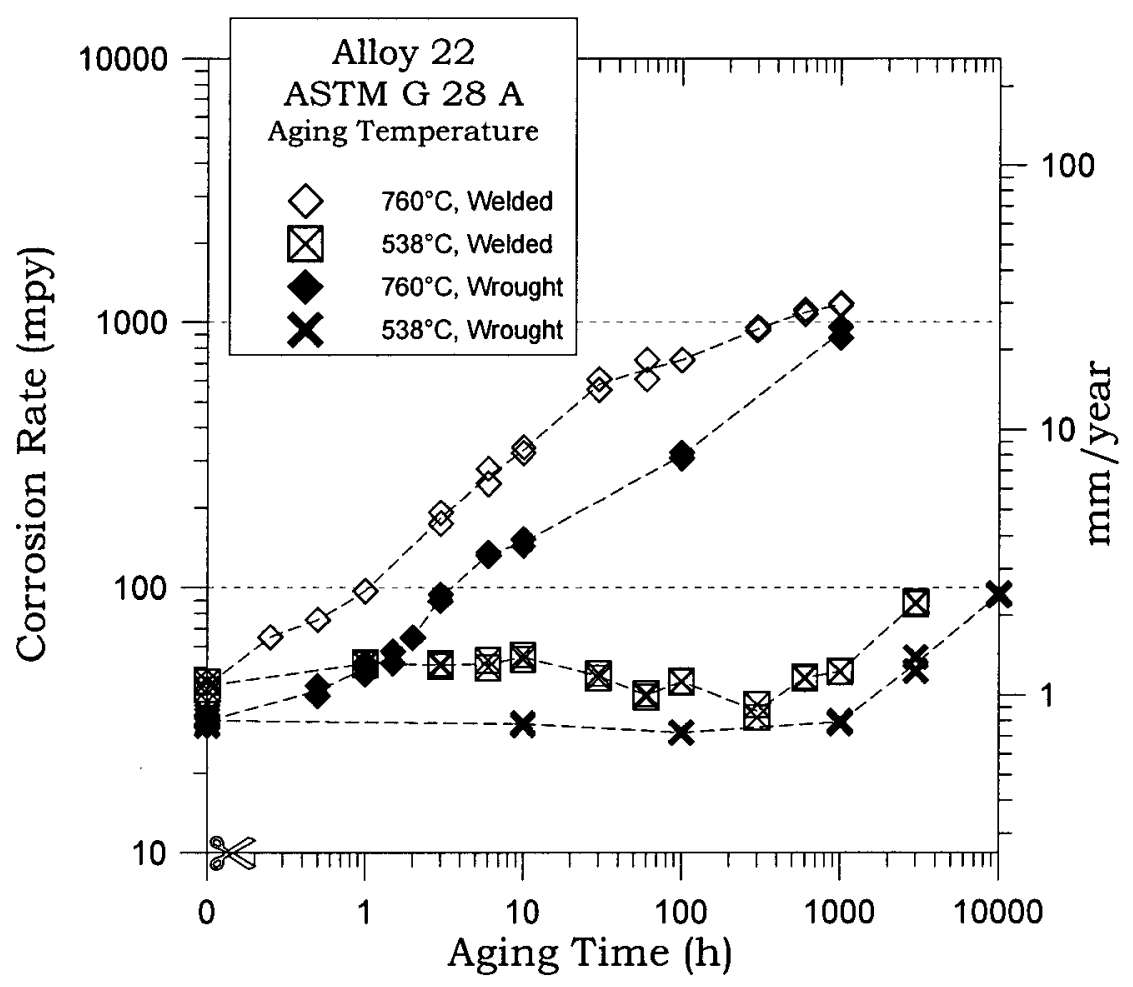

FIGURE 10: Corrosion rate in G 28 A solution for wrought and welded Alloy 22. 


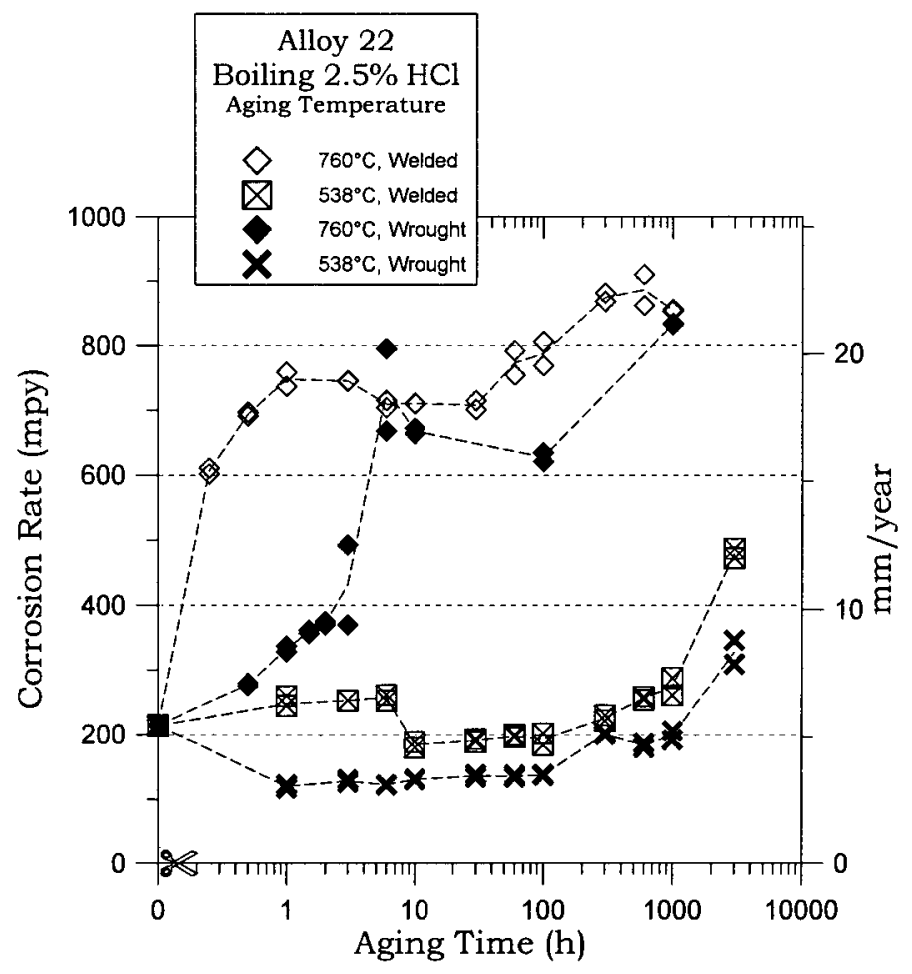

FIGURE 11: Corrosion rate in boiling 2.5\% $\mathrm{HCl}$ solution for wrought and welded Alloy 22.

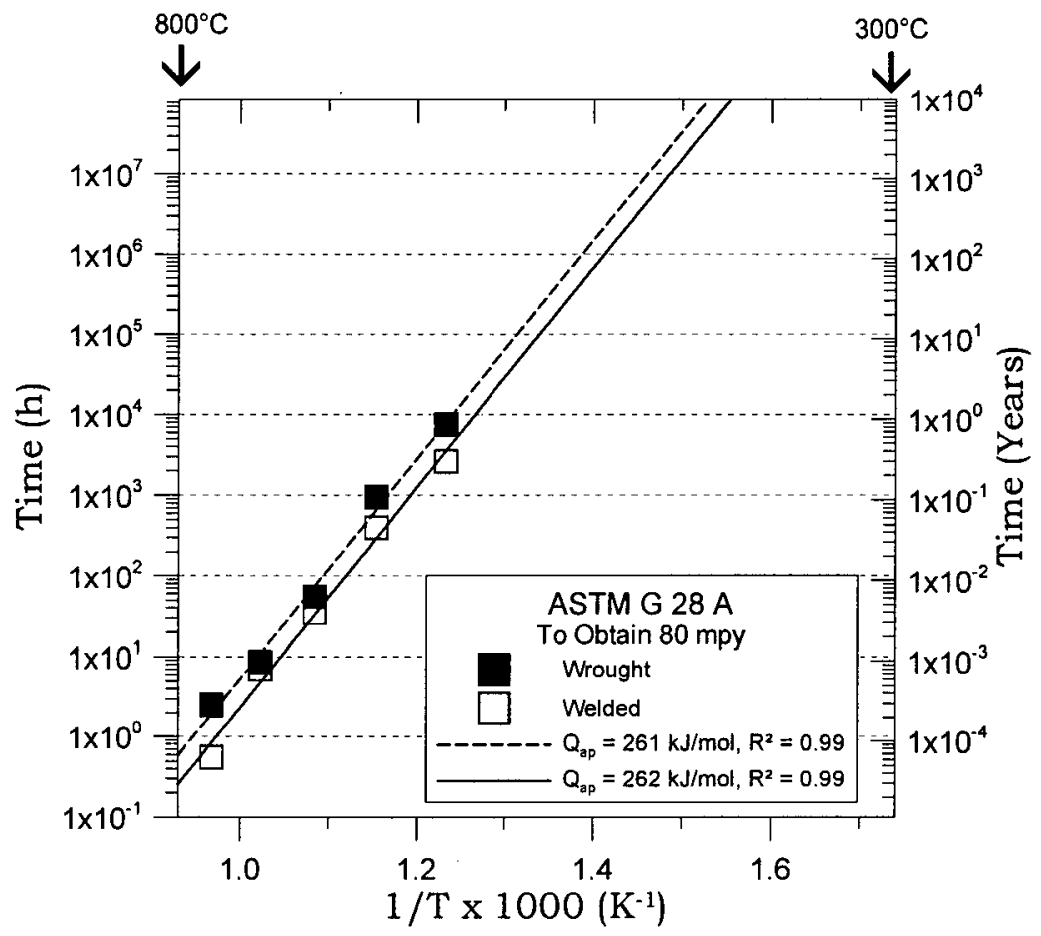

FIGURE 12: Arrhenius extrapolation for the corrosion behavior of wrought and welded Alloy 22. 


\section{Effect of Thermal Aging on} the Corrosion Behavior of Wrought and Welded Alloy 22

R.B. Rebak, T.S. Edgecumbe Summers, T. Lian, R.M. Carranza, J.R. Dillman, T. Corbin, P. Crook

This article was submitted to National Association of Corrosion Engineers Corrosion Expo 2002, Denver, CO, April 7-12, 2002

U.S. Department of Energy

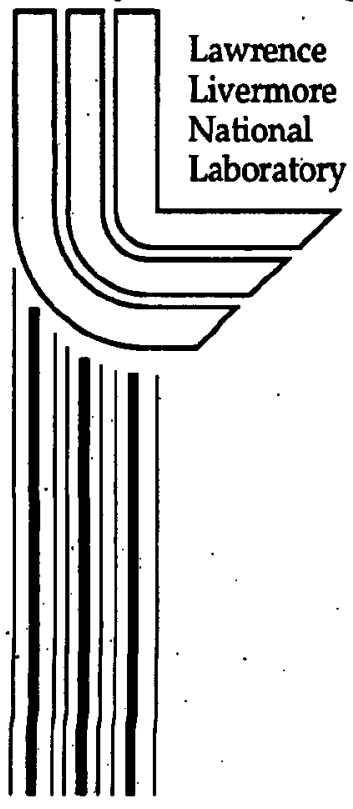

January 2; 2002 


\section{DISCLAIMER}

This document was prepared as an account of work sponsored by an agency of the United States Government. Neither the United States Government nor the University of California nor any of their employees, makes any warranty, express or implied, or assumes any legal liability or responsibility for the accuracy, completeness, or usefulness of any information, apparatus, product, or process disclosed, or represents that its use would not infringe privately owned rights. Reference herein to any specific commercial product, process, or service by trade name, trademark, manufacturer, or otherwise, does not necessarily constitute or imply its endorsement, recommendation, or favoring by the United States Government or the University of California. The views and opinions of authors expressed herein do not necessarily state or reflect those of the United States Government or the University of California, and shall not be used for advertising or product endorsement purposes.

This is a preprint of a paper intended for publication in a journal or proceedings. Since changes may be made before publication, this preprint is made available with the understanding that it will not be cited or reproduced without the permission of the author.

This report has been reproduced directly from the best available copy.

Available electronically at http;//www.dee.gov/bridge

Available for a processing fee to U.S. Department of Energy and its contractors in paper from

U.S. Department of Energy

Office of Scientific and Technical Information

P.O. Box 62

Oak Ridge, TN 37831-0062

Telephone: (865) 576-8401

Facsimile: (865) 576-5728

E-mail: reports@adonis.ostigov

Available for the sale to the public from

U.S. Department of Commerce

National Technical Information Service

5285 Port Royal Road

Springfield, VA 22161

Telephone: (800) 553-6847

Facsimile: (703) 605-6900

E-mail: orders@ntis.fedworld.gov

Online ordering: http://www.ntis,gov/ordering.htm

\section{OR}

Lawrence Livermore National Laboratory

Technical Information Department's Digital Library

http://www.llnl.gov/tid/Library.html 